\title{
Thinking on the Marketing and Promotion Mode of Agricultural Products in the Context of Internet Plus
}

\author{
Gaojie Jin \\ Wenzhou Vocational \& Technical College, Wenzhou. 325035, China \\ Jin-gaoj@163.com
}

Keywords: Agricultural products, promotion, marketing.

\begin{abstract}
With the advent of the mobile Internet era, marketing communication began to move into a new era of "micro-marketing". The rise of WeChat has led to a wave of business on the mobile Internet, that is, e-commerce is shifting from traditional ecommerce to mobile e-commerce. At the same time, smartphone upgrades have accelerated the shift. Therefore, the era of traditional online shopping will also stride into the era of micro-marketing.
\end{abstract}

\section{Introduction}

Micro-marketing is a method that companies use to promote their product information and to make profit for themselves. They make more people know and recognize their products, and further to make purchase of them through new media that is accepted and preferred by the public. And the micro-marketing in this paper is mainly WeChat marketing. The companies use Wechat moments to publicize the product information, so as to create more profits for the enterprise.

On April 29, 2013, Alibaba's jack ma invested \$586 million (3.6 billion yuan) to buy 18\% of Sina microblog. According to data analysis, over the past two years, Sina microblog's advertising revenue has become smaller and smaller. So why did Mr. Ma pay \$3.6bn for an 18 per cent stake in Sina microblog? The answer is simple. That is, Mr. Ma is catching on to the next trend, which will change the world in secret. The trend is that Taobao will change people's shopping habits again and transfer shopping habits from computer shopping to mobile shopping. It means a lot to marketing that the development of the mobile Internet has led to the explosion of smart phones and tablets in the past three years. From smartphones to smart TVS and even smart cars, advances in technology have made terminals ubiquitous. For marketing, the ubiquity of the terminal means that the brand reaches the consumer touch point in an unprecedented increase. Therefore, Sina microblog, as a micro terminal with great influence, has obvious value.

\section{Features of micro-marketing}

Compared with traditional marketing methods, micro-marketing has its unique characteristics. And it is its unique characteristics that make it popular among entrepreneurs. The features are as follows:

\subsection{High Efficiency and Convenience}

Wechat marketing is characterized by high efficiency and convenience. Taking WeChat as an example, the content should be simple and easy to understand when sending relevant information in 
the circle of friends, so that more people can understand it and are willing to read it. Compared with tedious context, convenient information is more acceptable to the public. Besides, content that is easy to understand is more widely accepted when product information is the same.

\subsection{Cost-effective}

Compared with traditional media, WeChat marketing costs much less than traditional media. And there are far more people watching the information of friends circle and public account than traditional media. Marketing on WeChat can yield more customers. What's more, the costs are low, which allow entrepreneurs to make bigger profits.

\subsection{High interactivity}

WeChat is first and foremost a chat and interactive platform. And then it is a tool for marketing. Interaction can strengthen the relationship and the interaction between enterprises and customers, and enhance the relationship between enterprises and old customers. At the same time, it can deepen the interaction with new customers and enhance the popularity of enterprises, so as to create greater profits.

\subsection{High transmission}

WeChat, as a chat platform, is used by a large number of users to communicate with friends and family. When the product information is accepted by customers, customers are willing to share the product with their friends. In this way, the product will be advertised for free, so that the product will be recognized by more people and be willing to buy.

\section{Status Quo and Existing Problems in the Development of Micro-Marketing}

\subsection{Current situation of micro-marketing development}

WeChat is a free app for instant messaging for smartphones launched by Tencent on January 21, 2011. WeChat supports voice messages, video, images and text messages sent free of charge (with a small amount of network traffic consumed) over the network across communication operators and across operating system platforms. At the same time, also can use the information through Shared streaming media content and location based social plugins "shake", "bottle", "friends", "public platform", "voice notepad" services such as plug-ins. As of January 2016, WeChat had 549 million monthly active users, making it the largest mobile instant messaging software in Asia. At present, WeChat has become an essential tool for people to connect with each other. And entrepreneurs are investing in WeChat, micro-marketing to create greater profits for the enterprise. According to the survey and research, over 98\% of Chinese enterprises (medium and large enterprises) have their own WeChat public account and working platform, providing more convenient services for the development of micro-marketing.

\subsection{Problems in the Development of Agricultural Product Micro-Marketing}

\section{1) Information Overload And Bombing Propaganda}

WeChat friends circle has been opened with all kinds of product information, and some of my feelings or ideas have been covered, which makes me feel that the circle of friends has become a product communication place. Sending product information in the circle of friends can bring better publicity to agricultural products. However, as many peers join in, especially the small ones, who 
have no public account or public platform, they can only rely on the product information of employees in the circle of friends to provide product popularity. This makes many people feel bored, and some people even choose not to read their friends' information. Therefore, this makes the product information more difficult to accept.

2) Single product information, no personalization

In micro-marketing, agricultural products are more often advertised for products, and few other elements are added to make the product information of the friend circle relatively simple. It is simply introducing the product information, which makes more people unwilling to see the information and choose some products with other factors and original materials for viewing. In this way, the popularity of individualized single products is reduced, and the popularity of highly personalized products is increased, creating higher profits for their agricultural products.

3) Lack Of Professional Management Personnel

At the beginning, as agricultural products attach importance to the development of micromarketing, product information is promoted on WeChat, microblog and other chat platforms, so as to increase product popularity. But because of the fact that the number of people joining agricultural products has increased in recent years and there is no dedicated collection and lack of talent to manage the development of micro-marketing, plus product information into a bombing campaign, customers have more and more choices. Therefore, the ability of products to be accepted diminishes the profitability of agricultural products.

\section{Micro-Marketing Positioning Of Agricultural Products}

As a brand of pure natural agricultural products, "agricultural products" adheres to the concept of bringing more primary ecological products to the metropolis and contributing to the quality city. WeChat is undoubtedly the best bridge between agricultural products and consumers in big cities. WeChat marketing public account of agricultural products is located in the expert of pure natural fruits and vegetables, providing the knowledge service of fruits and vegetables encyclopedia and the healthy life consultant of pure natural fruits and vegetables products for metropolitan consumers.

Nearly half of the 400 million WeChat users are white collar and business people. Therefore, the target fans of the public account are white-collar workers who pursue a high quality of life and business people with middle and high-end income, mainly women. By pushing the knowledge of fruit and vegetable health maintenance encyclopedia every day, the introduction of healthy vegetables, fruit and vegetable beauty and beauty maintenance knowledge to attract the constant attention of fans. At the same time, the product sales link is added to the pushed content for sales. For example, in the article introducing fruit cucumber, add the sales link of Taobao store, and guide the fans to enter Taobao store to purchase products.

The public account adopts the operation mode of "we media" and e-commerce. While spreading the brand, the consumer circle is established to improve consumers' recognition of alpine organic fruits and vegetables, and promote the development of new channels of WeChat e-commerce with the word of mouth. Thus, the product can be sold and the customer relationship is stable.

\section{Development Strategy of Agricultural Product Micro-Marketing}

Only by solving some major problems in the development of micro-marketing can agricultural products better disseminate product information and make the product more famous. Therefore, solving these problems has become a top priority for agriculturists.

The opening account is shown in figure 1. 


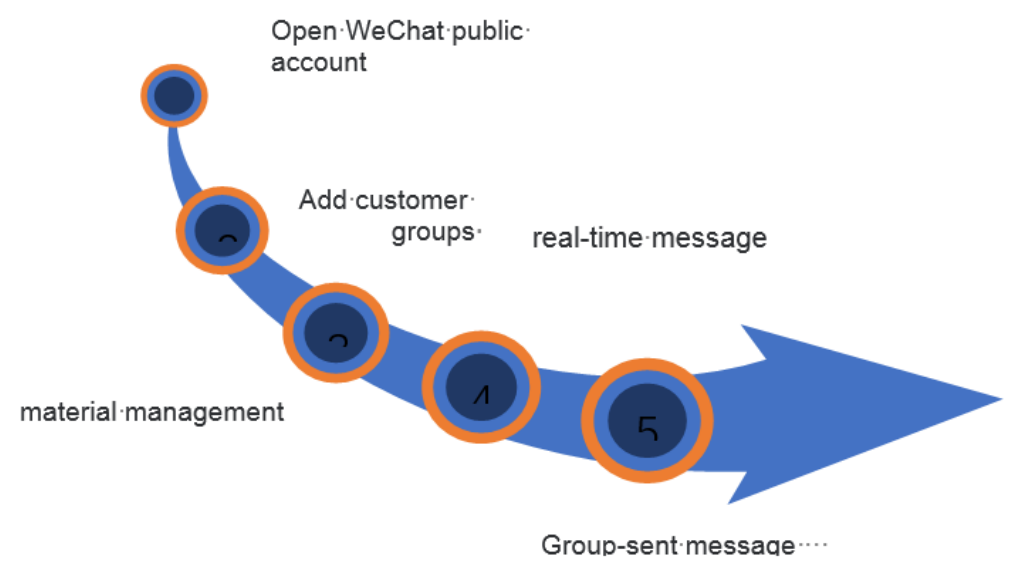

Figure 1 account opening

\subsection{Open Wechat Public Account}

Follow the exclusive WeChat account of "agricultural products" in advance and set the account information and logo head. Set to add automatic reply, automatic message reply, automatic keyword reply, if necessary, you can choose to bind the public number of mobile phone assistant. After 500 fans apply for certification, to enhance credibility.

\subsection{Add customer groups}

It is divided into new customers, old customers, star group and ungrouped. Later, customer groups can be added according to requirements

\subsection{Material management}

Plan and edit single text and multiple text message as the mass material which comes from the official website of "agricultural products" or from other sources.

\subsection{Send Group Messages}

Three pictures and text messages are sent in groups every day. One is pushed according to the three categories of fruit and vegetable beauty, healthy family vegetables and fruit and vegetable health maintenance and add a product sales link to each message. You can select groups of customers to push, such as new product special promotion activities for new customers and gratitude and feedback activities for old customers, and then choose to push different contents. In addition, the push appeal points that can be adopted include thematic push and interactive push.

\subsection{Real-Time Information}

Respond to questions and feedback from fans every day

\section{Good publicity}

The content of product promotion should not be complicated, it should be simple and easy to understand. When editing promotional material, you should not only promote product information. There are a lot of consumers like to see some interesting life topics, so when editing product 
information should focus on the information that can arouse consumers' attention. Then, some product information is added into the information, so as to enable more consumers to watch and be willing to watch, making these consumers become fans of agricultural products. Only when consumers become fans of agricultural products will they be more willing to buy them.

\subsection{Set Goals}

It is important to identify the target group for the product information to be released. As long as the target group of consumption is set, and accurate product information can achieve the double effect with half the effort, creating greater profits for agricultural products. Otherwise, it will take more than half the effort to achieve the expected results.

\subsection{Cultivate Professional Talents}

Today's society is a society of talents. Only with talents can we better create profits for agricultural products. Therefore, in micro-marketing, talents are also indispensable, especially managerial and editorial talents. Management personnel can well manage the general scheme of micro-marketing and provide advice for the development of agricultural products in micromarketing. Editors add colorful information to product information, making it more acceptable to consumers. The cooperation of management talents and editing talents can provide great convenience for the development of agricultural products in micro-marketing and create greater profits for agricultural products.

\subsection{Good Interaction between Agricultural Products and Consumers}

Interaction can maintain the relationship between agricultural products and consumers. Therefore, good interaction with consumers is also an important step in the development of agricultural products in micro-marketing. Only by making consumers fans of agricultural products can we achieve better. Because consumers feel good things will be willing to share with people around them, so that they can publicize products for free for agricultural products, thus creating greater profits.

\section{Conclusions}

Agricultural product micro-marketing is to promote enterprises and create profits on platforms like WeChat and Microblog. In a word, micro-marketing of agricultural products is "managing" first and "selling" second. The two come together to make profits for companies. In micromarketing, we must first establish a good image of agricultural products enterprises and build a good image for enterprises. Because this will make it easier for consumers to accept the company's products. Secondly, consumers should really feel good about the product. Because in this way, we can not only publicize agricultural products for free, but also bring new and old customers to agricultural products one after another, making them become fans of agricultural products, thus creating profits. Today's society is a society in the Internet era, which combines online and offline, so as to bring better benefits to enterprises. Micro-marketing will occupy most consumers' minds today and even in the future. If micro-marketing is done well now, it will be better in the future, so as to create greater profits for agricultural products. 


\section{References}

[1]Magdalini Vasileiou,Jennifer Rowley. Marketing and promotion of e-books in academic libraries[J]. Journal of Documentation,2011,67(4).

[2]Jennifer Rowley. Promotion and marketing communications in the information marketplace[J]. Library Review,1998,47(8).

[3]Nicole T. Moulding. "Love your body, move your body, feed your body": Discourses of self-care and social marketing in a body image health promotion program[J]. Critical Public Health,2007,17(1).

[4]Pisal Yenradee,Kittipong Piyamanothorn. Integrated aggregate production planning and marketing promotion: model and case study[J]. International Journal of Management Science and Engineering Management,2011,6(2).

[5]Mah Manuel W,Tam Yat Cho,Deshpande Sameer. Social marketing analysis of 20 [corrected] years of hand hygiene promotion.[J]. Infection Control \& Hospital Epidemiology,2008,29(3).

[6]Gosselin Pierre,Poitras Philippe. Use of an internet "viral" marketing software platform in health promotion.[J]. Journal of Medical Internet Research,2008,10(4).

[7]I. Kagan RN, PhD,E. Biran RN, BA,L. Telem RN, BA,N. Steinovitz RN, BA,D. Alboer RN, BA,K.L. Ovadia RNM, MPHA,S. Melnikov RN, PhD. Promotion or marketing of the nursing profession by nurses[J]. International Nursing Review,2015,62(3).

[8]M. Stead,A. M. MacKintosh,A. Findlay,L. Sparks,A. S. Anderson,K. Barton,D. Eadie. Impact of a targeted direct marketing price promotion intervention (Buywell) on food-purchasing behaviour by low income consumers: a randomised controlled trial[J]. Journal of Human Nutrition and Dietetics,2017,30(4).

[9]Rall M,Meyer S M. The role of the registered nurse in the marketing of primary healthcare services, as part of health promotion.[J]. Curationis,2006,29(1).

[10]Blair J E. Social marketing: consumer focused health promotion.[J]. AAOHN journal : official journal of the American Association of Occupational Health Nurses,1995,43(10).

[11] García España F,March Cerdá J C,Gómez Villegas I. [Social marketing applied to condom promotion: a proposal for intervention in groups at risk for sexually transmitted diseases].[J]. Gaceta sanitaria / S.E.S.P.A.S,1994,8(43).

[12]Fontana S A. Marketing health promotion: hitting or missing the target in occupational health.[J]. AAOHN journal : official journal of the American Association of Occupational Health Nurses,1993,41(10).

[13] Wilson B R,Hayes T J. Marketing health promotion to corporations: overcoming the cost/benefit problem through a customer orientation.[J]. Journal of ambulatory care marketing,1991,5(1).

[14]Grace V M. The marketing of empowerment and the construction of the health consumer: a critique of health promotion.[J]. International journal of health services : planning, administration, evaluation,1991,21(2).

[15]. Social marketing campaign swaps condoms for bottle tops.[J]. Global AIDSnews : the newsletter of the World Health Organization Global Programme on AIDS,1993(2).

[16]Xia Yuan,Deshpande Sameer,Bonates Tiberius. Effectiveness of Social Marketing Interventions to Promote Physical Activity Among Adults: A Systematic Review.[J]. Journal of physical activity \& health,2016,13(11).

[17]Martin Boisen,Kees Terlouw,Peter Groote,Oscar Couwenberg. Reframing place promotion, place marketing, and place branding - moving beyond conceptual confusion[J]. Cities,2017.

[18]Ergun Gide,S M Riad Shams. The role of web-based promotion on the development of a relationship marketing model to enable sustainable growth[J]. Procedia Computer Science,2011,3.

[19]S.K. Patil,Pranita Pradhan. Library Promotion Practices and Marketing of Library Services: A Role of Library Professionals[J]. Procedia - Social and Behavioral Sciences,2014,133.

[20]Icard Larry D,Bourjolly Joretha N,Siddiqui Nushina. Designing social marketing strategies to increase African Americans' access to health promotion programs.[J]. Health \& Social Work,2003,28(3). 